\title{
Structure elucidation of $\beta$-sitosterol with antibacterial activity from the root bark of Malva parviflora
}

\author{
Mesfin Medihin Ododo ${ }^{1 *}$, Manash Kumar Choudhury² and Ahmed Hussen Dekebo²
}

\begin{abstract}
The powder of root bark of Malva parviflora (Malvaceae) was successively extracted with petroleum ether (b.p. $60-80^{\circ} \mathrm{C}$ ), chloroform and ethanol. The chloroform extract showed antibacterial activity against Staphylococcus aureus and Escherichia coli, whereas the ethanolic extract showed antibacterial activity against only S. aureus. The chloroform extract, after column chromatographic separation on silica gel using petroleum ether:chloroform (3:1) as eluent, furnished $98 \mathrm{mg}$ of white crystalline compound. The yield of the compound is $0.316 \%(\mathrm{w} / \mathrm{W})$. The compound has a melting point of $134-136^{\circ} \mathrm{C}$ and the $R_{f}$ value 0.56 in benzene:chloroform:acetone (1:15:1) on silica gel TLC. The compound was characterized as $\beta$-sitosterol by physical properties, chemical test, spectral analysis (FTIR, NMR and MS) and comparing the data obtained from the literature.
\end{abstract}

Keywords: Malva parviflora, Antibacterial activity, Ethanolic extract, Chloroform extract, $\beta$-Sitosterol

\section{Background}

Populations throughout Africa, Asia and Latin America use traditional medicine to meet their primary healthcare needs (WHO 2002). Although animal parts and minerals have been used, the primary source of traditional medication is herbal medicines (WHO 2000). The majority of Ethiopians depend on herbal medicines as their only source of healthcare, especially in rural areas. Medicinal plants and knowledge of their use provide a vital contribution to human and livestock healthcare needs throughout the country areas (World Bank 2004). Malva parviflora is one of the most widely used herbs in Ethiopia.

Malva parviflora (family: Malvaceae) is native to Northern Africa, Europe and Asia. In Ethiopia, the plant is commonly known as Lit (in Amharic), Lita (in Afaan Oromo), Enkefteha (in Tigrigna) and Uka (in Wolaitta) languages. It often grows in waste places and agricultural farmlands. Malva parviflora is an annual, a biennial or a perennial herb plant. The plant is growing up to $40 \mathrm{in}$., has a deep strong tap root system and the leaves are dark green and have 5-7 toothed, rounded lobes (Fig. 1).

\footnotetext{
*Correspondence: medhinmes@gmail.com

${ }^{1}$ Chemistry Department, Aksum University, Aksum, Ethiopia Full list of author information is available at the end of the article
}

Malva parviflora has been widely used in many parts of the world for curing various diseases. In South Africa, Xhosa people use a poultice made from the whole plant parts of the plant to treat boils, inflammed purulent wounds and swellings (Afolayan et al. 2008). A hot poultice of leaf is used to treat wounds and swellings in La Reunion, and tea of the leaf is taken as a nervine tonic and used as a taenicide and for profuse menstruation (Sharma and Ali 1999). A dried powder or an infusion of the leaves and roots is used to clean wounds and sores in Lesotho (Afolayan et al. 2008). Tea of the leaf is used for treating dry, irritative cough and bronchitis (Ishtiaq et al. 2012). A decoction of the leaves and roots is also used as a hair rinse to remove dandruff and to soften the hair, and tea of the leaf is also used to clean out the mother's system after childbirth (Mukul 2012). Seeds are demulcent, used to treat cough and ulcers in the bladder (Sharma and Ali 1999). In Ethiopia, the fresh root bark of M. parviflora is chopped into small pieces and applied on the damaged skin surfaces to treat furuncles, carbuncles, wound infections and other related ailments.

The skin infections such as furuncles and carbuncles are universally caused by Staphylococcus aureus (McCaig et al. 2006). The most common bacteria causing wound infection 


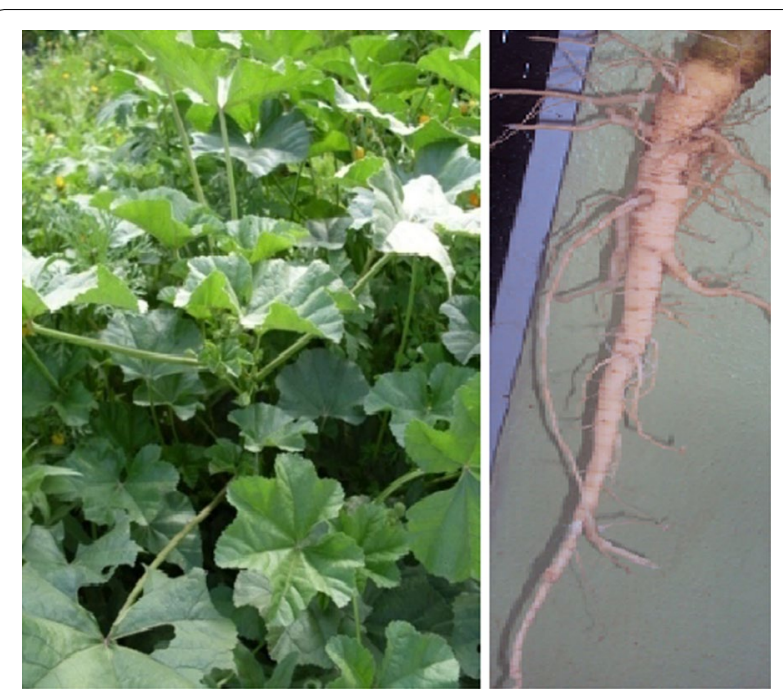

Fig. 1 Malva parviflora and its root

is S. aureus followed by Escherichia coli (Shittu et al. 2002; Ahmed et al. 2007). Staphylococcus aureus (S. aureus) is a Gram-positive bacterium that can live as a commensal organism on the skin and in the nose and throat (Ryu et al. 2014). Human beings are a natural reservoir for S. aureus; and asymptomatic colonization is far more common than infection (Chambers 2001). Approximately $30 \%$ of healthy people are asymptomatically colonized by $S$. aureus (Ryu et al. 2014). A transmission of $S$. aureus may occur by direct contact to a colonized carrier (Chambers 2001). Escherichia coli is a Gram-negative bacillus that belongs to the Escherichia genus which is made up of species present in the human and other animal intestine. When eliminated in the environment together with feces, $E$. coli contaminates water, soil and food. E. coli strains may cause various infections including infections of the skin wounds (Moş et al. 2010).

Although $M$. parviflora plays a significant role in traditional medicine in many countries including Ethiopia, only a limited study has been done to scientifically explore antibacterial activity, and there have been no previous reports on the isolation and structural characterization of the bioactive compounds present in this plant. Thus, the present study aimed to evaluate antibacterial activity of root bark of $M$. parviflora for further structural characterization of bioactive compound(s).

\section{Methods}

\section{Collection of the plant material and description the study} area

Fresh plant material was collected at the agricultural farmlands area, around Shanto Town (latitude $07^{\circ} 01^{\prime} 28.2^{\prime \prime} \mathrm{N}$ and longitude $037^{\circ} 55^{\prime} 09.9^{\prime \prime} \mathrm{E}$ ), Damot Pulassa Woreda, Wolaitta Zone, SNNPR, Ethiopia, in
October 2012 towards the end of the rainy season. A voucher specimen (083488) has been deposited at the National Herbarium, Addis Ababa University, Addis Ababa, Ethiopia.

\section{Preparation of the plant material}

The root parts were washed with tap water followed by distilled water. The bark part was then separated from the root and dried under shade. The dried samples were powdered using a local coffee grinder.

\section{Extraction}

The powdered root bark of $M$. parviflora was successively extracted by Soxhlet extraction with petroleum ether (b.p. $60-80{ }^{\circ} \mathrm{C}$ ), chloroform and ethanol using standard procedure as described by Jones and Kinghorn (2006). Fifteen grams of the powder was extracted in $300 \mathrm{~mL}$ of the solvents. The extractions were carried out for $6 \mathrm{~h}$ by petroleum ether, $10 \mathrm{~h}$ by chloroform and $15 \mathrm{~h}$ by ethanol. The solvents in the filtrates were then evaporated completely using water bath at their boiling points. The dried crude extracts were weighed, and the percentage (\%) yields of the extractions process were calculated. The processes were repeated a total of three extractions.

\section{Preparation of extracts solution for antibacterial activity assay}

The solutions (each $30 \mathrm{mg} / \mathrm{mL}$ ) of the ethanolic and chloroform extracts were prepared by dissolving their crude extracts in sterile distilled water and dimethylsulfoxide (DMSO) respectively. The solvents were hence used as a negative control. Serial twofold dilution of each extract was prepared in a concentration ranging from 25 to $2.5 \mathrm{mg} / \mathrm{mL}$ for the determination of minimum inhibitory concentration (MIC) value. The antibacterial activity of the root bark of $M$. parviflora was compared to gentamicin (Ivee Aqua Epz Ltd, Kenya) which is a commercial synthetic antibiotic to $S$. aureus and $E$. coli pathogens (Ghalem 2014).

\section{Test bacteria}

Two bacterial species namely S. aureus (ATCC 25923) and E. coli (ATCC 20922) were used for antibacterial activity assay. The bacteria pathogens were obtained from Ethiopian Health and Nutrition Research Institute (EHNRI), Addis Ababa, Ethiopia.

\section{Antibacterial activity assay}

The antibacterial activity of the extracts was evaluated by Agar Well Diffusion method as described by Mattana et al. (2010) with little modification. Both bacteria strains were inoculated into $10 \mathrm{~mL}$ of sterile nutrient broth [Bulux Laboratories (P) Ltd, India] in respective 
conical flasks and incubated at $37{ }^{\circ} \mathrm{C}$ for $24 \mathrm{~h}$. Nutrient agar (Merck KGaA, Germany) medium was prepared, poured into sterilized Petri dishes and allowed to solidify inside the biological safety cabinet. The cultures were then swabbed on the surface of sterile nutrient agar plates using a sterile cotton swab. Three wells $(6 \mathrm{~mm}$ in diameter) were drilled into each plate, and the solutions of the extracts were added, until wells were filled. After in upright position incubation at $37^{\circ} \mathrm{C}$ for $24 \mathrm{~h}$, the diameter of inhibition zones were measured in millimeter $(\mathrm{mm})$. The antibacterial activity assay was determined as the MIC value, which is the minimum concentration of the extract that could inhibit the growth of tested bacteria.

\section{Isolation and purification}

The chloroform extract was chromatographed on silica gel 60 (0.063-0.200 mm particle size, Merck KGaA, Germany) column (11 cm length and $2 \mathrm{~cm}$ cross section). The silica gel was weighed using a ratio of $10 \mathrm{~g}$ of the adsorbent to $1 \mathrm{~g}$ of the extract. First, the slurry of weighed silica gel $(8 \mathrm{~g})$ was prepared using $100 \%$ petroleum ether and poured into the column. The crude extract $(1 \mathrm{~g})$ was dissolved in $2 \mathrm{~mL}$ of chloroform in a beaker and adsorbed in $2 \mathrm{~g}$ of the silica gel. The mixture was stirred at room temperature until all the chloroform was evaporated off, and put on top of a column of previously packed. Initially, it was eluted with $100 \%$ petroleum ether, and the polarity was gradually increased by adding chloroform at various ratios (Table 1). Totally, 118 fractions were collected (10 $\mathrm{mL}$ each) until the compounds were completely eluted from the column. The fractions were monitored by TLC, and then similar fractions having the same $R_{f}$ values were combined together (Table 1 ).

Fractions (80-89), showed a major spot with two faint spots, were kept in a fridge at $4{ }^{\circ} \mathrm{C}$ for $4 \mathrm{~h}$ after addition of a little methanol. The crystals were formed at the bottom of the flask and separated from the mother liquor. The light yellow crystals were further purified by crystallization from methanol (white crystal, $98 \mathrm{mg}$ ). The yield of the compound is $0.316 \%(\mathrm{w} / \mathrm{w})$. The purity of isolated compound was determined by TLC and melting point before submitting to the spectral analysis.

\section{Thin layer chromatography (TLC)}

A small amount of crystals was dissolved in chloroform and spotted on the TLC plate using pre-coated aluminium with $0.20 \mathrm{~mm}$ thick silica gel $60 \mathrm{~F}_{254}(20 \times 20 \mathrm{~cm}$, Merck KGaA, Germany). Then the TLC plate was run by the solvent system of benzene:chloroform:acetone (1:15:1), respectively. After drying at room temperature, the spot was visualized by placing the plate in iodine vapor. The retardation factor $\left(R_{f}\right)$ value was then measured.

\section{Melting point measurement}

A melting point (m.p.) measurement was performed by procedure as described by Brittain (2009) on a SA-300H digital melting point apparatus. A few crystals of the compound were placed in a thin walled glass capillary tube and then inserted into the side of the heating block via the hole provided in the apparatus. The compound

Table 1 Column chromatographic separation of chloroform extract

\begin{tabular}{|c|c|c|c|c|c|c|}
\hline Fractions & Solvent & $\begin{array}{l}\text { Volume } \\
\text { collected }(\mathrm{mL})\end{array}$ & $\begin{array}{l}\text { Combined } \\
\text { fractions }\end{array}$ & $\begin{array}{l}R_{f} \text { value for } \\
\text { major spot }\end{array}$ & $\begin{array}{l}\text { Number } \\
\text { of spots }\end{array}$ & TLC solvent \\
\hline $1-13$ & PE (100\%) & 130 & $1-13$ & 0.22 & 6 & PE: $\mathrm{CHCl}_{3}(4: 1)$ \\
\hline $14-29$ & $\mathrm{PE}: \mathrm{CHCl}_{3}(10: 1)$ & 160 & $14-29$ & 0.56 & 4 & PE: $\mathrm{CHCl}_{3}(2: 1)$ \\
\hline \multirow[t]{2}{*}{$30-40$} & $\mathrm{PE}: \mathrm{CHCl}_{3}(9: 1)$ & 110 & $34-35$ & 0.42 & 2 & PE: $\mathrm{CHCl}_{3}(1: 1)$ \\
\hline & & & $36-40$ & 0.44 & 3 & \\
\hline $41-48$ & PE: $\mathrm{CHCl}_{3}(8: 1)$ & 80 & $42-48$ & 0.50 & 4 & PE: $\mathrm{CHCl}_{3}(1: 2)$ \\
\hline $49-55$ & $\mathrm{PE}: \mathrm{CHCl}_{3}(7: 1)$ & 70 & $49-55$ & 0.50 & 3 & PE: $\mathrm{CHCl}_{3}(1: 2)$ \\
\hline $56-62$ & PE: $\mathrm{CHCl}_{3}(6: 1)$ & 70 & $56-62$ & 0.41 & 2 & PE: $\mathrm{CHCl}_{3}(1: 2)$ \\
\hline $63-67$ & PE: $\mathrm{CHCl}_{3}(5: 1)$ & 50 & $63-67$ & 0.20 & 4 & $\mathrm{CHCl}_{3}(100 \%)$ \\
\hline $68-74$ & PE: $\mathrm{CHCl}_{3}(4: 1)$ & 70 & $68-74$ & 0.20 & 4 & $\mathrm{CHCl}_{3}(100 \%)$ \\
\hline \multirow[t]{2}{*}{$75-89$} & PE: $\mathrm{CHCl}_{3}(3: 1)$ & 150 & $75-77$ & 0.55 & 4 & $\mathrm{CHCl}_{3}: \operatorname{Act}(15: 1)$ \\
\hline & & & $80-89$ & 0.50 & 3 & \\
\hline 90-101 & PE: $\mathrm{CHCl}_{3}(2: 1)$ & 120 & 90-101 & 0.21 & 3 & $\mathrm{CHCl}_{3}:$ Act $(9: 1)$ \\
\hline \multirow[t]{2}{*}{$102-133$} & PE: $\mathrm{CHCl}_{3}(1: 1)$ & 320 & $102-110$ & 0.46 & 2 & $\mathrm{CHCl}_{3}: \operatorname{Act}(10: 1)$ \\
\hline & & & $111-118$ & 0.44 & 3 & \\
\hline
\end{tabular}

Italics characters are used for the conditions that the compound has been isolated

$\mathrm{PE}$ petroleum ether, $\mathrm{CHCl}_{3}$ chloroform, Act acetone 
was then heated until it was melted. The temperature at which the solid began to melt, and that at which it was completely liquid, was recorded as the melting point range of the compound.

\section{Spectra measurement}

FTIR spectrum was recorded on a Perkin Elmer 1330 spectrometer with $\mathrm{KBr}$ pellets. ${ }^{1} \mathrm{H}$ and ${ }^{13} \mathrm{C}$ NMR spectra were measured on a Bruker DPX $400 \mathrm{MHz}$ and $100.06 \mathrm{MHz}$ spectrometer respectively. High-resolution electrospray ionization mass spectrometry (HR-ESIMS) measurement was carried out on a Q-Tof Micro YA263 spectrometer in the positive ion mode.

\section{Test for steroid}

The test for steroid was performed by Liebermann-Burchard reaction as described by Rajput and Rajput (2012). A few crystals of isolated solid compound were dissolved in chloroform, and a few drops of concentrated sulfuric acid were added to the solution followed by the addition of 3 drops of acetic anhydride. The solution turned violet blue and finally green.

\section{Statistical analysis}

The extraction efficiency of the solvents and the zones of inhibition induced by the plant extracts against tested bacteria were given as mean \pm SD (where SD is standard deviation) of three replicates. Difference between means zones of inhibition and the standard was determined using students' test (t-test). The level of statistical significance was set at $P \leq 0.05$.

\section{Results and discussion}

\section{Extraction}

Petroleum ether gave light yellow coloured solid $(1.18 \pm 0.07 \%)$, chloroform yielded light brown coloured solid $(3.22 \pm 0.42 \%)$ and ethanol resulted yellow coloured amorphous solid $(9.62 \pm 0.84 \%)$ crude extracts.
The results revealed that different solvents have been found to extract different active principles depending on their polarity, and ethanol could extract the highest amount of materials present in the plant which indicates that the root bark of $M$. parviflora contains the largest proportion of polar components. The percent yield of petroleum ether is very low and could not allow further chemical study. In the present study, we conducted only the antibacterial activity evaluation on chloroform and ethanolic crude extracts.

\section{Antibacterial activity assay}

The chloroform extract showed antibacterial activity against S. aureus (Fig. 2b) and E. coli (Fig. 3a) with the same diameter of zones of inhibition $(15 \pm 0.41 \mathrm{~mm})$ and MIC value of $20 \mathrm{mg} / \mathrm{mL}$, whereas the ethanolic extract showed antibacterial activity against only $S$. aureus (Fig. 2a) with diameter of zone of inhibition $(18 \pm 3.20 \mathrm{~mm})$ and MIC value of $15 \mathrm{mg} / \mathrm{mL}$. The results revealed that $S$. aureus more sensitive to ethanolic extract than chloroform extract. This is due to stronger extraction capacity of ethanol could have produced greater number of active constituents responsible for antibacterial activity against $S$. aureus. However, only chloroform extract showed antibacterial activity against $E$. coli. The fact that the root bark of M. parviflora showed antibacterial activity against $S$. aureus and $E$. coli might justify the use of this plant in traditional medicine for the treatment of the diseases caused by tested bacteria pathogens.

It was observed that $S$. aureus (Gram positive bacterium) is highly susceptible to inhibition by ethanolic extract, whereas E. coli (Gram negative bacterium) did not show growth of inhibition. This may probably be due the morphological differences particularly cell wall composition between the two bacteria species. The Grampositive bacteria have only an outer peptidoglycan layer which is not effective permeability barrier, whereas the most of the Gram-negative bacteria possess an outer
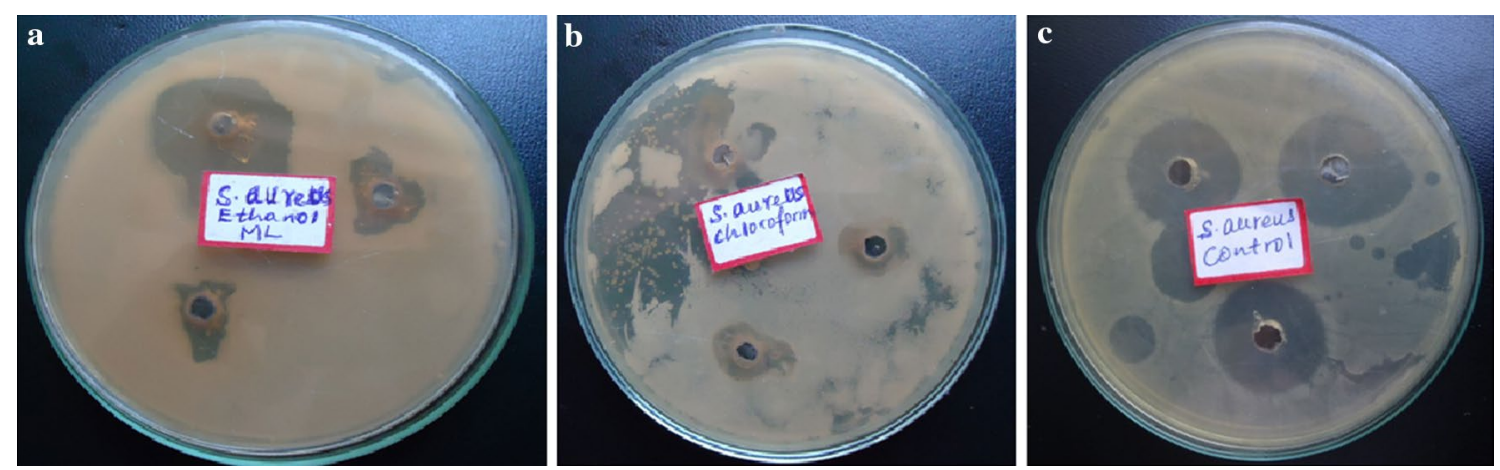

Fig. 2 Growth inhibition of S. aureus by a ethanolic extract, $\mathbf{b}$ chloroform extract, $\mathbf{c}$ gentamicin 

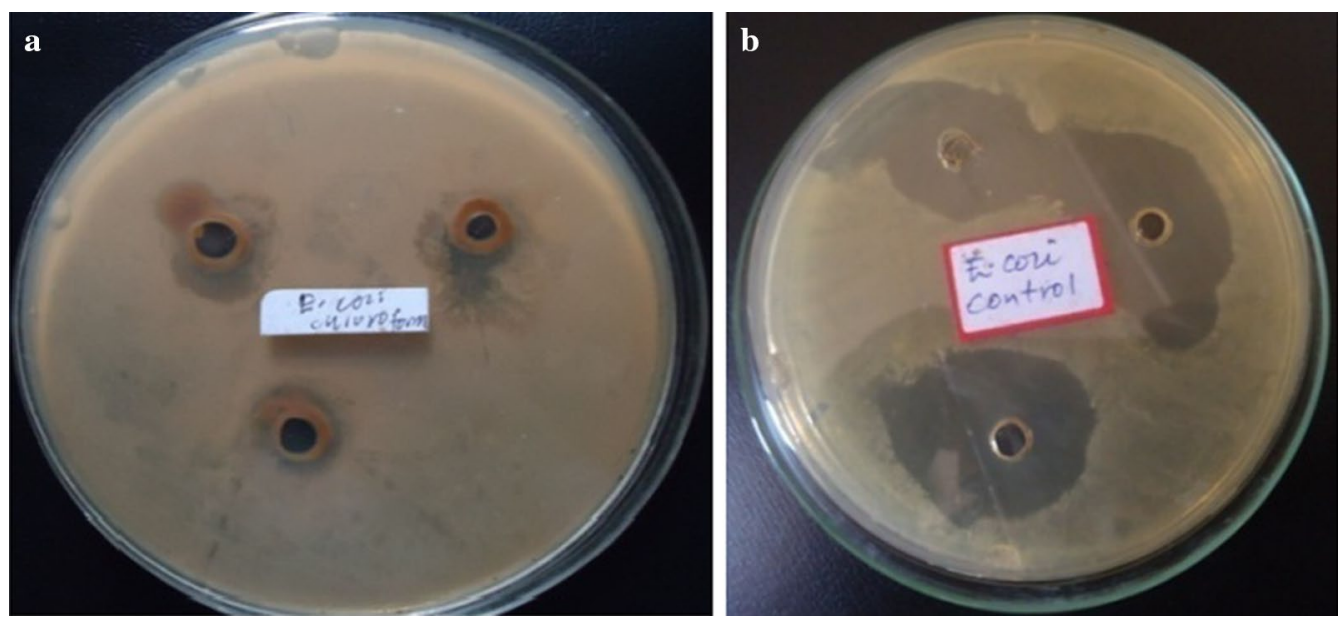

Fig. 3 Growth inhibition of E. coli by $\mathbf{a}$ chloroform extract, $\mathbf{b}$ gentamicin

multilayered peptidoglycan and a phospholipidic bilayer. This makes the cell wall impermeable to most of the drugs (Ghansar et al. 2012). Gentamicin (a positive control) caused zones of inhibition $24 \pm 1.21 \mathrm{~mm}$ (Fig. 2c) and $25 \pm 1.04 \mathrm{~mm}$ (Fig. 3b) against S. aureus and E. coli respectively. The statistical evaluation revealed that the root bark of $M$. parviflora showed significantly lower inhibitory activity against both tested bacteria than the standard antibiotic. Sterile distilled water (Fig. 4a) and DMSO (Fig. 4b) did not show any antibacterial activity against tested bacteria.

There have been a few previous reports on the antibacterial activity of $M$. parviflora. The root of $M$. parviflora inhibited the growth of $S$. aureus and E. coli with the zones of inhibition ranged between 0.20 and $0.43 \mathrm{~mm}$ (Shale et al. 2005). According to Tadeg et al. (2005) report, the root of M. parviflora showed zone of inhibition $(20 \pm 0.0 \mathrm{~mm})$ against $S$. aureus, but no zone of inhibition was noted against E. coli. Furthermore, Kalayou et al. (2012) performed antibacterial activity on the leaves of $M$. parviflora, and the zones of inhibition were $9.70 \pm 1.10 \mathrm{~mm}$ for $S$. aureus and $10.25 \pm 2.20 \mathrm{~mm}$ for E. coli. In general, the zones of inhibition obtained in the present study are different from results in the previous reports. This is due to several variables which influence the bioactive plant constituents against tested bacteria such as the environmental and climatic conditions under which the plant grow, choice of plant extracts, choice of extraction methods and antimicrobial test method as well (Ncube et al. 2008).

\section{TLC, melting point and steroid test}

The isolated compound showed a single spot with $R_{f}$ value 0.56 and has m.p. of $134-136{ }^{\circ} \mathrm{C}$. A sharp m.p. (just
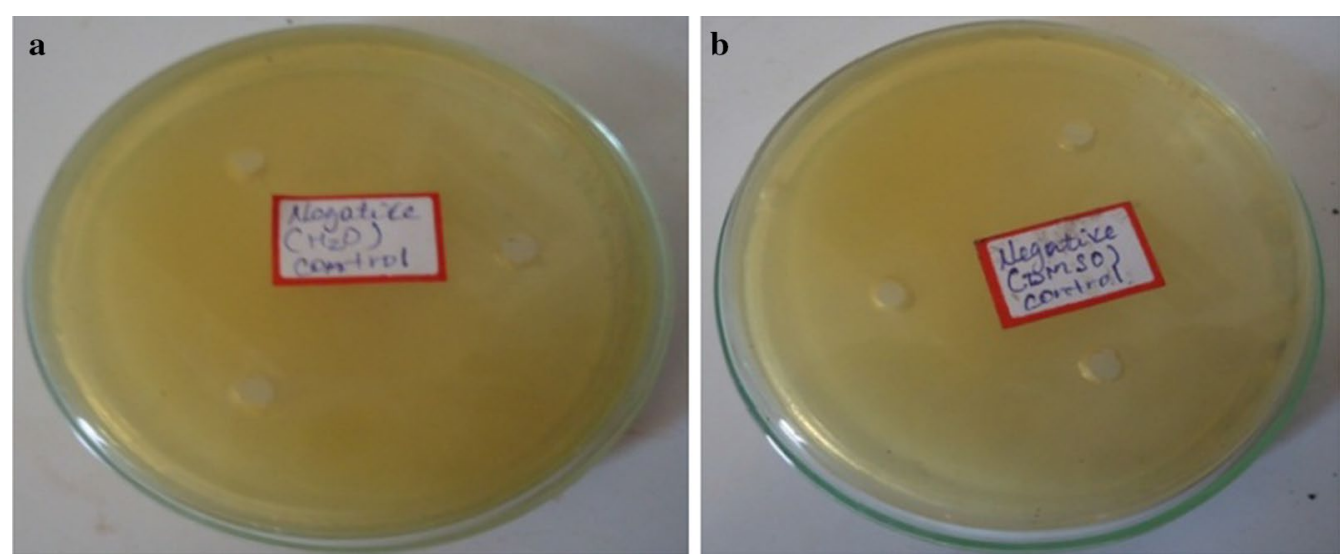

Fig. 4 No growth inhibitions of S. aureus and E. coli by a sterile distilled water, b DMSO 
a narrow range of $1-2{ }^{\circ} \mathrm{C}$ ) indicates that the high purity of the isolated compound (Brittain 2009). The m.p. result of the compound is very close to the literature value (134$135{ }^{\circ} \mathrm{C}$ ) for $\beta$-sitosterol (Hang and Dussault 2010). In steroid test, the compound showed a violet-blue colour, which finally turned into green in Liebermann-Burchard reaction indicating the presence of steroid (Rajput and Rajput 2012).

\section{Spectra analysis}

The FTIR spectrum (Fig. 5) showed absorptions band $\left(\mathrm{cm}^{-1}\right)$ for $\mathrm{OH}$ at $3427.85, \mathrm{CH}_{3}$ at 2959.64 and 2868.72, $\mathrm{CH}_{2}$ at 2868.72 and 2852.27, unconjugated olefinic $(\mathrm{C}=\mathrm{C})$ at 1641.91, cyclic methylene groups $\left(\mathrm{CH}_{2}\right) \mathrm{n}$ at 1464.59, gem-dimethyl $\left(-\mathrm{CH}\left(\mathrm{CH}_{3}\right)_{2}\right)$ group at 1382.09 and $\mathrm{C}-\mathrm{OH}$ of secondary alcohol at 1052.35 .

The integration of ${ }^{1} \mathrm{H}$ NMR spectrum (Fig. 6) showed the presence of fifty hydrogens: $\operatorname{six} \mathrm{CH}_{3}$, eleven $\mathrm{CH}_{2}$, nine $\mathrm{CH}$ and one $\mathrm{OH}$ groups (Table 2). The appearance the singlets at $\delta 0.70$ and 1.03 confirming the presence of two $\mathrm{CH}_{3}$ attached to quaternary carbons. The appearance of the complex multiplets at $\delta 2.29$ and 2.32 is revealed that the two $\mathrm{CH}_{2}$ adjacent to carbon attached to $\mathrm{OH}$ group. The multiplet at $\delta 3.54$ is due to a proton connected to the carbon which attached with $\mathrm{OH}$ group. The overlapping triplet signal also appeared for $\mathrm{CH}$ at $\delta 5.37$ indicated that the presence of one olefinic proton.

The ${ }^{13} \mathrm{C}$ NMR spectrum (Fig. 7) exhibited the existence of 29 carbons. The carbons could be classified as representing $\mathrm{CH}_{3}, \mathrm{CH}_{2}, \mathrm{CH}$ or quaternary carbon (QC) by DEPT- 135 . The DEPT-135 spectrum (Fig. 8) indicated the presence of 26 carbons: six peaks appeared up due $\mathrm{CH}_{3}$ groups, nine peaks up for $\mathrm{CH}$ groups and peaks appeared down indicated the presence of eleven $\mathrm{CH}_{2}$ groups (Table 2). The absence of three signals in the DEPT-135 spectrum confirmed the presence of three QC atoms. In ${ }^{13} \mathrm{C}$ NMR spectrum, the recognizable signals at 140.77 and 121.73 are assigned for double bond between carbon atoms in position 5 and 6 $\left(\mathrm{C}_{5}=\mathrm{C}_{6}\right)$, respectively. The signal at $\delta 71.8$ is assigned for $\mathrm{C}_{3} \beta-\mathrm{OH}$ group, and the signals at $\delta 11.89$ and 19.42 are assigned for angular methyl carbons for $\mathrm{C}_{19}$ and $\mathrm{C}_{18}$, respectively. The chemical shift value for $C_{18}$ is lower

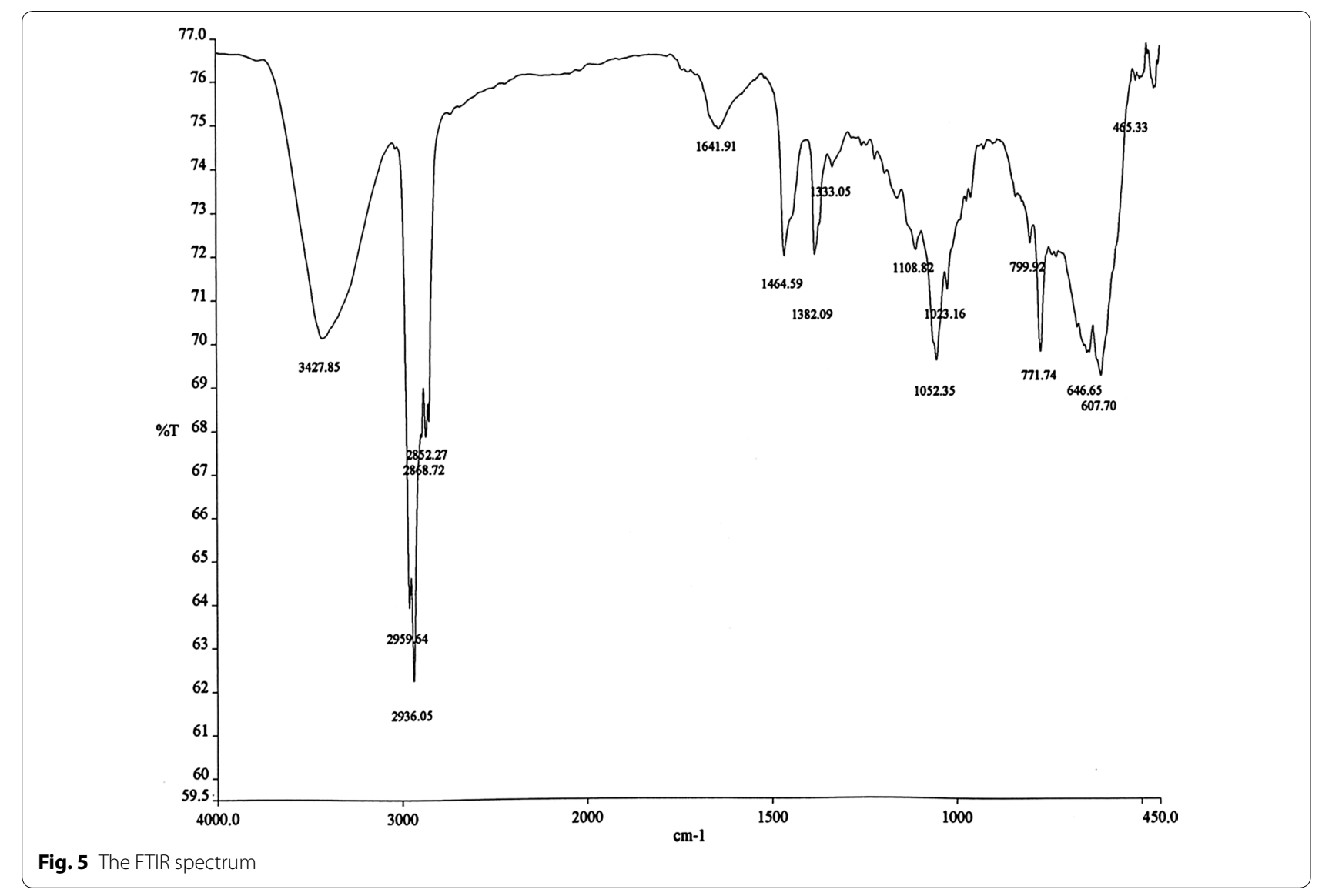




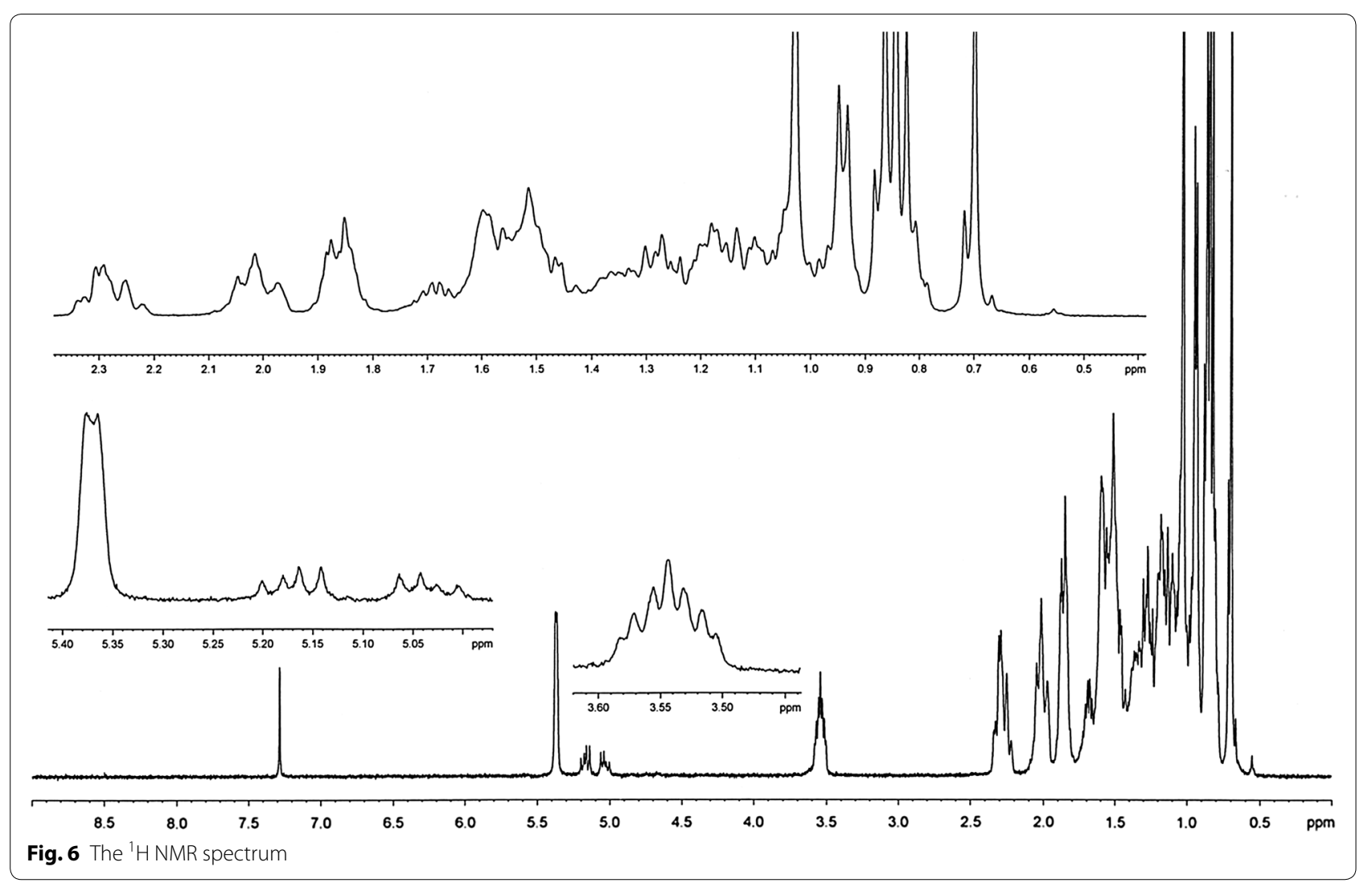

due to $\gamma$-gauche interaction that increases the screening of the $\mathrm{C}_{18}$. However, the loss of $\mathrm{H}$-atom in $\mathrm{C}_{6}$ results in decrease in screening of the $\mathrm{C}_{19}$ leading to increase in ${ }^{13} \mathrm{C}$ NMR chemicals shift to higher frequency (Pateh et al. 2009).

The mass molecular ion of the compound appeared in HR-ESI-MS spectrum (Fig. 9) at m/z 437.3521 which is approximately 23 higher than the expected because the compound was ionized under positive mode HR-ESI by addition of $\mathrm{Na}$ atom. This indicated that the isolated compound with molecular weight of 414.3521, in good agreement with the theoretical value (calculated for $\mathrm{C}_{29} \mathrm{H}_{50} \mathrm{O}$, 414.7066). The characteristic peak was given at $\mathrm{m} / \mathrm{z}$ 413.2449 that corresponds to (M-1) or loss of $\mathrm{H}$. The spectrum showed the most intense peak at $\mathrm{m} / \mathrm{z} 301.1362$ that corresponds to (M-113) or loss of $\left(-\mathrm{C}_{8} \mathrm{H}_{17}\right)$. Other ion peak at $\mathrm{m} / \mathrm{z} 231.1145$ is due to the loss of side-chain and ring $\mathrm{D}$ fragment, $-\mathrm{C}_{13} \mathrm{H}_{27}$ that corresponds to the $\mathrm{M}-183$.

The observed chemical shift values (Table 2) in NMR spectra are very close to values reported in the literature for $\beta$-sitosterol (Patra et al. 2010).

Based on ${ }^{1} \mathrm{H}$ NMR, ${ }^{13} \mathrm{C}$ NMR, DEPT-135 and HRESI-MS data, molecular formula of the isolated compound was determined to be $\mathrm{C}_{29} \mathrm{H}_{50} \mathrm{O}$. Since the isolated compound gave positive test for steroids, all of the other structures other than steroids were rejected. Based upon the functional group analysis, it was found that the nature of oxygen was hydroxyl which is supported by FTIR data. The FTIR spectrum also showed the presence of one $\mathrm{C}=\mathrm{C}$ in the structure. So, the steroids with 
Table 2 The observed ${ }^{1} \mathrm{H}$ and ${ }^{13} \mathrm{C}$ NMR spectra data in $\mathrm{CDCl}_{3}$ with a drop of methanol- $d_{4}$ at 400 and $100.06 \mathrm{MHz}$, respectively

\begin{tabular}{|c|c|c|c|}
\hline \multirow[t]{2}{*}{ Position } & \multirow[t]{2}{*}{ Type } & \multicolumn{2}{|c|}{ Chemical Shift, $\delta(\mathrm{ppm})$ value } \\
\hline & & ${ }^{13} \mathrm{C}$ NMR & ${ }^{1} \mathrm{H}$ NMR (multiplicity) \\
\hline 1 & $\mathrm{CH}_{2}$ & 37.28 & $1.46(\mathrm{~m})$ \\
\hline 2 & $\mathrm{CH}_{2}$ & 31.69 & $1.56(\mathrm{~m})$ \\
\hline 3 & $\mathrm{CH}(\mathrm{OH})$ & 71.82 & $3.54(\mathrm{~m})$ \\
\hline 4 & $\mathrm{CH}_{2}$ & 42.33 & $2.32(\mathrm{~m})$ \\
\hline 5 & $\mathrm{QC}(=)$ & 140.77 & - \\
\hline 6 & $\mathrm{CH}(=)$ & 121.73 & 5.37 (overlapping, t) \\
\hline 7 & $\mathrm{CH}_{2}$ & 31.93 & $2.04(\mathrm{~m})$ \\
\hline 8 & $\mathrm{CH}$ & 31.93 & $1.69(\mathrm{~m})$ \\
\hline 9 & $\mathrm{CH}$ & 50.16 & $1.55(\mathrm{~m})$ \\
\hline 10 & QC & 36.51 & - \\
\hline 11 & $\mathrm{CH}_{2}$ & 21.11 & $1.52(\mathrm{~m})$ \\
\hline 12 & $\mathrm{CH}_{2}$ & 39.80 & $1.51(\mathrm{~m})$ \\
\hline 13 & QC & 42.34 & - \\
\hline 14 & $\mathrm{CH}$ & 56.79 & $1.50(\mathrm{~m})$ \\
\hline 15 & $\mathrm{CH}_{2}$ & 24.33 & $1.58(\mathrm{~m})$ \\
\hline 16 & $\mathrm{CH}_{2}$ & 28.27 & $1.85(\mathrm{~m})$ \\
\hline 17 & $\mathrm{CH}$ & 56.08 & $1.45(\mathrm{~m})$ \\
\hline 18 & $\mathrm{CH}_{3}$ & 11.89 & $0.70(\mathrm{~s})$ \\
\hline 19 & $\mathrm{CH}_{3}$ & 19.42 & $1.03(\mathrm{~s})$ \\
\hline 20 & $\mathrm{CH}$ & 36.17 & $1.60(\mathrm{~m})$ \\
\hline 21 & $\mathrm{CH}_{3}$ & 18.84 & 0.94 (overlapping, d) \\
\hline 22 & $\mathrm{CH}_{2}$ & 33.98 & $0.93(\mathrm{~m})$ \\
\hline 23 & $\mathrm{CH}_{2}$ & 26.11 & $1.15(\mathrm{~m})$ \\
\hline 24 & $\mathrm{CH}$ & 45.86 & $1.38(\mathrm{~m})$ \\
\hline 25 & $\mathrm{CH}$ & 29.19 & $1.57(\mathrm{~m})$ \\
\hline 26 & $\mathrm{CH}_{3}$ & 19.84 & 0.84 (overlapping, d) \\
\hline 27 & $\mathrm{CH}_{3}$ & 19.06 & $0.86(d)$ \\
\hline 28 & $\mathrm{CH}_{2}$ & 23.10 & $1.10(\mathrm{~m})$ \\
\hline 29 & $\mathrm{CH}_{3}$ & 12.01 & 0.82 (overlapping, t) \\
\hline- & $\mathrm{OH}$ & - & $1.98(\mathrm{~s})$ \\
\hline
\end{tabular}

other functional groups were rejected. In general, based on the physical properties (crystal with white color and m.p.), steroid test and spectroscopic data (IR, NMR and MS) and comparing the data in the scientific literature, the structure of the isolated compound was determined to be $\beta$-sitosterol (Fig. 10).

$\beta$-Sitosterol is a natural micronutrient found in the cells and membranes of all oil producing plants, fruit, vegetables, grains, seeds and trees (Sen et al. 2012). It is commercially available in preparative amounts only as mixtures with other phytosterols typically stigmasterol and campesterol (Hang and Dussault 2010). $\beta$-Sitosterol has been proven to be a safe, nontoxic, effective nutritional supplement and has amazing potential health benefits in many diverse applications including antibacterial activity (Sen et al. 2012). Earlier experimental studies have shown that $\beta$-sitosterol has antibacterial activity against different bacteria species including $S$. aureus and E. coli. According to Sen et al. (2012) and Joy et al. (2012) reports, $\beta$-sitosterol inhibited the growth of $S$. aureus $(17.83 \pm 0.58 \mathrm{~mm})$ and E. coli $(14.5 \pm 1.84 \mathrm{~mm})$ and $S$. aureus $(13 \mathrm{~mm})$ and $E$. coli $(14 \mathrm{~mm})$ respectively. So, the study suggested that the presence of $\beta$-sitosterol in chloroform extract of the root bark M. parviflora might contribute to its potency of growth inhibition against tested bacteria.

\section{Conclusions}

The antibacterial activity assay showed that the ethanolic and chloroform extracts of the root bark M. parviflora possess active compound to inhibit the growth of bacteria species: S. aureus and E. coli. This is in agreement with the use of this plant in traditional medicine for the treatment of furuncles, carbuncles, wound infections and other related ailments. In chromatographic separation, $\beta$-sitosterol was isolated from chloroform extract of the root bark of $M$. parviflora. Although 


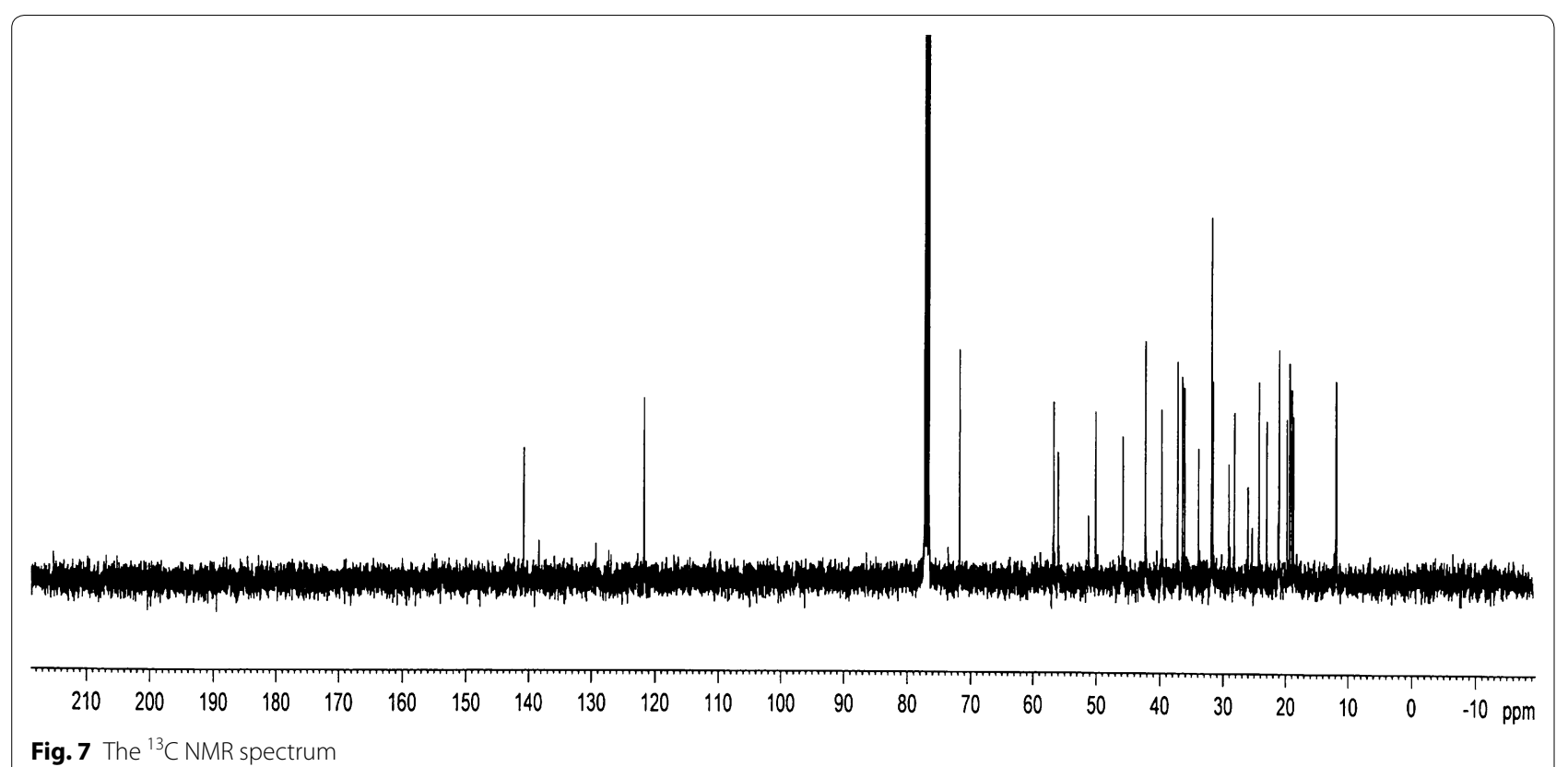

Fig. 7 The ${ }^{13} \mathrm{C}$ NMR spectrum

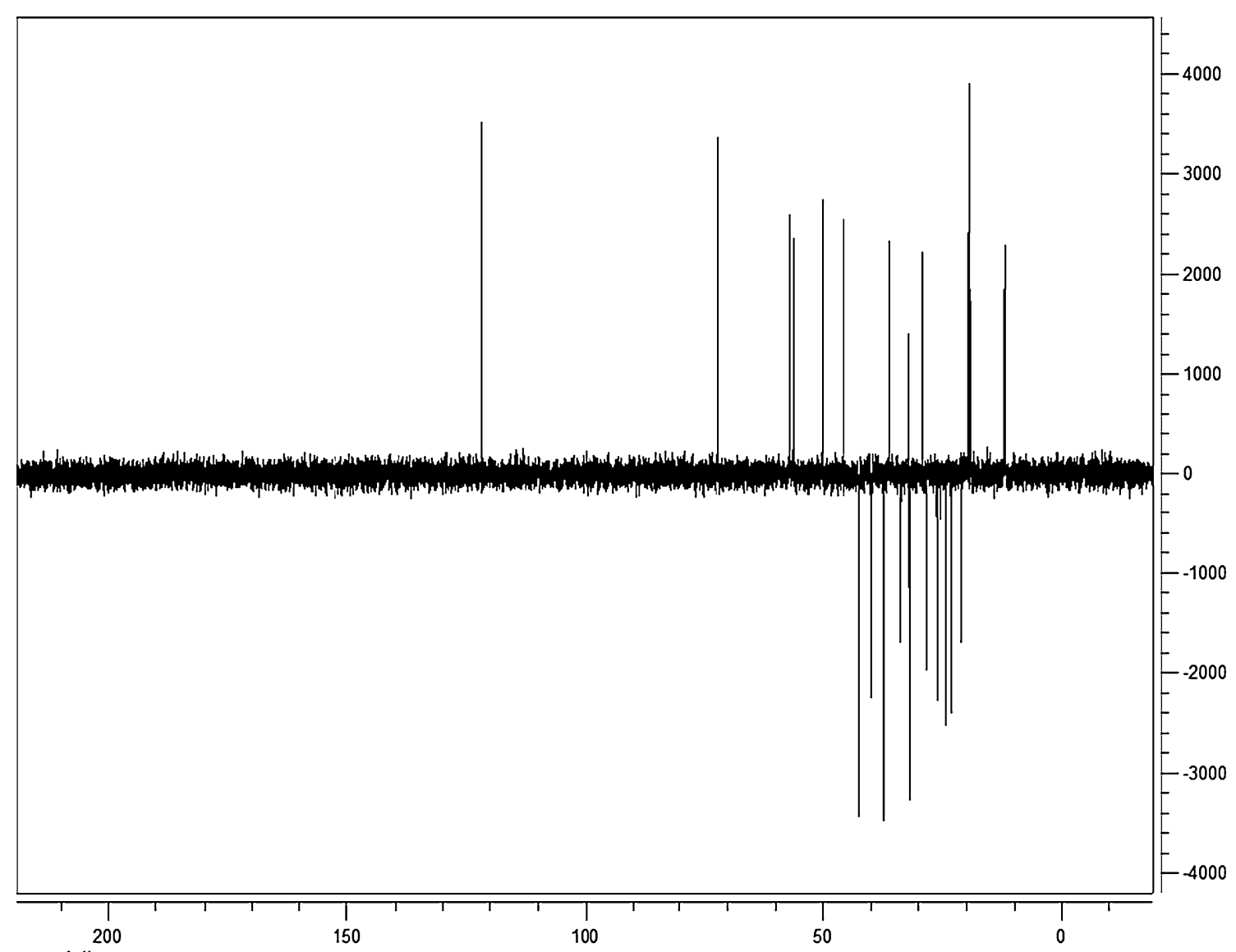

ppm (t1)

Fig. 8 The DEPT-135 spectrum 


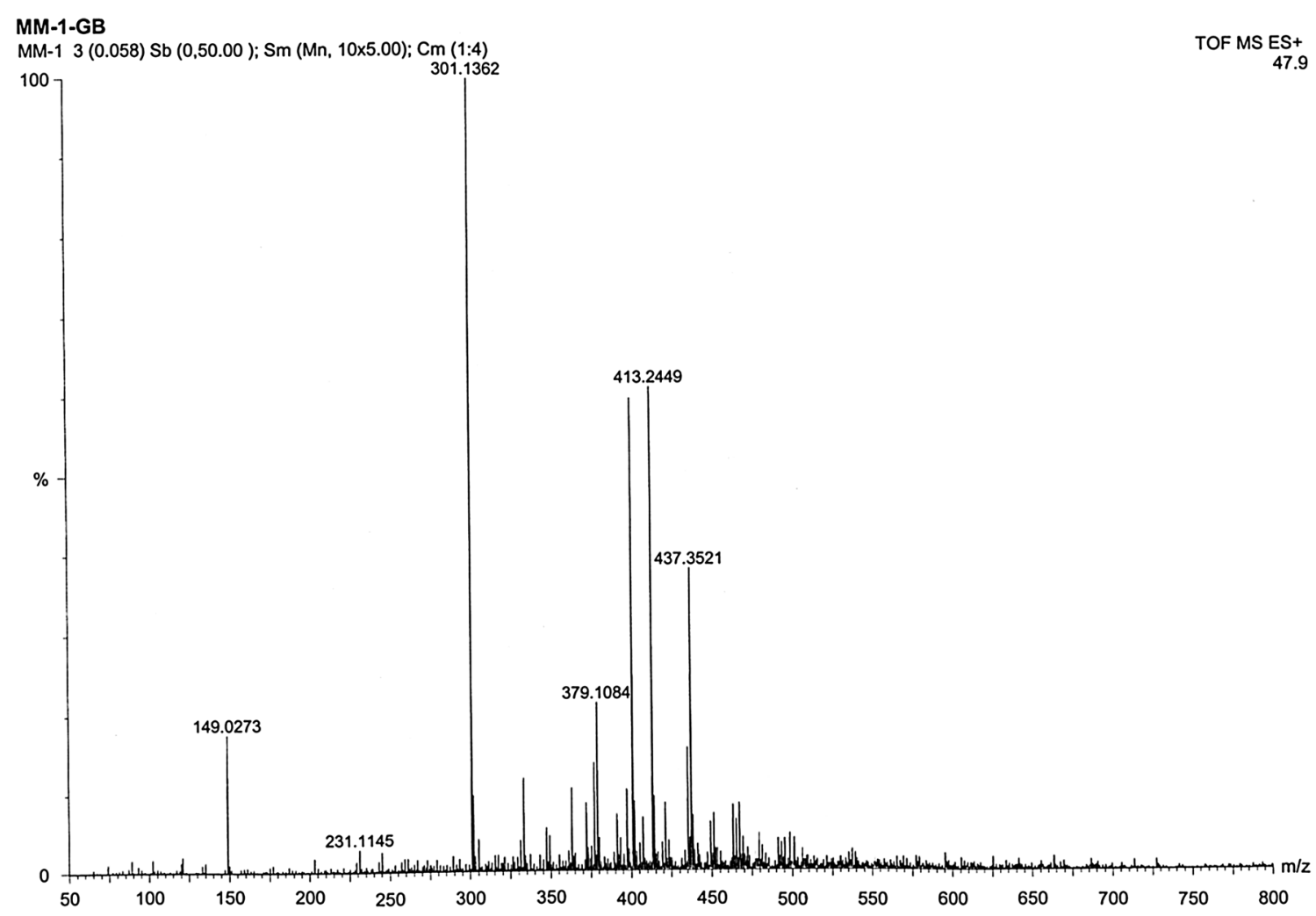

Fig. 9 The HR-ESI-MS spectrum<smiles>CC[C@H](CC[C@@H](C)[C@H]1CCC2C3CC=C4CC(O)CC[C@]4(C)C3CCC21C)C(C)C</smiles>

Fig. 10 The structure of $\beta$-sitosterol

$\beta$-sitosterol is a known natural product, this is the first report of the isolation from this plant and its structural characterization.

\section{Authors' contributions}

MMO collected and prepared the sample, designed experiments, interpreted the data and prepared the manuscript. MKC and AHD are supervisors of this research and guided the progress of the work. All authors read and approved the final manuscript.

\section{Author details}

${ }^{1}$ Chemistry Department, Aksum University, Aksum, Ethiopia. ${ }^{2}$ Chemistry Department, Dilla University, P.O. Box 419, Dilla, Ethiopia.

\section{Acknowledgements}

This work was financially supported by Ministry of Education of the Federal Democratic Republic of Ethiopia.

\section{Competing interests}

The authors declare that they have no competing interests.

Received: 15 April 2016 Accepted: 21 July 2016

Published online: 29 July 2016

\section{References}

Afolayan AJ, Aboyade OM, Sofidiya MO (2008) Total phenolic content and free radical scavenging activity of Malva parviflora L. (Malvaceae). J Biol Sci 8(5):945-949

Ahmed M, Alam SN, Khan O, Manzar S (2007) Post-operative wound infection: a surgeon's dilemma. Pak J Surg 23(1):41-47

Brittain CG (2009) Using melting point to determine purity of crystalline solids. https://www.chm.uri.edu/mmcgregor/chm228/use_of_melting_point_ apparatus.pdf. Accessed 10 Apr 2016

Chambers HF (2001) The changing epidemiology of Staphylococcus aureus? Emerg Infect Dis 7(2):178-182

Ghalem BR (2014) Effect of essential oils of Artemisia arborescens on Escherichia coli Staphylococcus aureus and Pseudomonas aeruginosa. J Plant Sci 2(6-1):1-4

Ghansar NH, Bhopale SU, Prabhune VS (2012) In Vitro studies of antimicrobial properties of extracts from Unani medicinal plants. Int J Pharm Bio Sci 3(1):B-240-B-249

Hang J, Dussault P (2010) A concise synthesis of $\beta$-sitosterol and other phytosterols. Steroids 75(12):879-883

Ishtiaq S, Saeed-UI-Hassan S, Niaz U, Saeed MA (2012) Identification and evaluation of counter-irritant potential of crude extract of Malva parviflora L. by WHO recommended methods. Pak J Pharm Sci 25(3):589-594 
Jones WP, Kinghorn AD (2006) Extraction of plant secondary metabolites. In: Sarker SD, Latif Z, Gray Al (eds) Natural products isolation, 2nd edn. Humana Press, Totowa

Joy HH, Krishna V, Jignesh S, Sanjay ST, Roshan A, Vijay S (2012) In-Silico drug designing using $\beta$-sitosterol isolated from Flaveria trinervia against peptide deformylase protein to hypothesize bactericidal effect. Int J Pharm Pharm Sci 4(2):192-196

Kalayou S, Haileselassie M, Gebre-egziabher G, Tiku'e T, Sahle S, Taddele H, Ghezu M (2012) In-vitro antimicrobial activity screening of some ethnoveterinary medicinal plants traditionally used against mastitis, wound and gastrointestinal tract complication in Tigray Region, Ethiopia. Asian Pac JTrop Biomed 2(7):512-522

Mattana CM, Satorres SE, Sosa A, Fusco M, Alcaráz LE (2010) Antibacterial activity of extracts of Acacia aroma against methicillin-resistant and methicillin-sensitive Staphylococcus. Braz J Microbiol 41:581-587

McCaig LF, McDonald LC, Mandal S, Jernigan DB (2006) Staphylococcus aureusassociated skin and soft tissue infections in ambulatory care. Emerg Infect Dis 12(11):1715-1723

Moş I, Micle O, Zdrâncă M, Mureşan M, Vicaş L (2010) Antibiotic sensitivity of the Escherichia coli strains isolated from infected skin wounds. Farmacia 58(5):637-645

Mukul (2012) Malva parviflora | Find Me A Cure www.findmeacure. com/2012/08/06/malva-parviflora/. Accessed 5 Sept 2012

Ncube NS, Afolayan AJ, Okoh Al (2008) Assessment techniques of antimicrobial properties of natural compounds of plant origin: current methods and future trends. Afr J Biotechnol 7(12):1797-1806

Pateh UU, Haruna AK, Garba M, Iliya I, Sule IM, Abubakar MS, Ambi AA (2009) Isolation of stigmasterol, $\beta$-sitosterol and 2-hydroxyhexadecanoic acid methyl ester from the rhizomes of Stylochiton lancifolius Pyer and Kotchy (Araceae). Niger J Pharm Sci 8(1):19-25
Patra A, Jha S, Murthy PN, Manik Sharone A (2010) Isolation and characterization of stigmast-5-en-3 $\beta$-ol ( $\beta$-sitosterol) from the leaves of Hygrophila spinosa T. Anders. Int J Pharma Sci Res 1(2):95-100

Rajput AP, Rajput TA (2012) Isolation of stigmasterol and $\beta$-sitosterol from chloroform extract of leaves of Corchorus fascicularis Lam. Int J Biol Chem 6(4):130-135

Ryu S, Song Pl, Seo CH, Cheong H, Park Y (2014) Colonization and infection of the skin by S. aureus: immune system evasion and the response to cationic antimicrobial peptides. Int J Mol Sci 15:8753-8772

Sen A, Dhavan P, Shukla KK, Singh S, Tejovathi G (2012) Analysis of IR, NMR and antimicrobial activity of $\beta$-sitosterol isolated from Momordica charantia. Sci Secure J Biotech 1(1):9-13

Shale TL, Stirk WA, van Staden J (2005) Variation in antibacterial and antiinflammatory activity of different growth forms of Malva parviflora and evidence for synergism of the anti-inflammatory compounds. J Ethnopharmacol 96:325-330

Sharma SK, Ali M (1999) A new stigmastane derivative isolated from root of Malva parviflora. Ind J Chem 38B:746-748

Shittu AO, Kolawole DO, Oyedepo EAR (2002) A study of wound infections in two health institutions in lle-lfe, Nigeria. Afr J Biomed Res 5:97-102

Tadeg H, Mohammed E, Asres K, Gebre-Mariam T (2005) Antimicrobial activities of some selected traditional Ethiopian medicinal plants used in the treatment of skin disorders. J Ethnopharmacol 100:168-175

WHO (2000) General guidelines for methodologies on research and evaluation of traditional medicine. World Health Organization, Geneva

WHO (2002) Policy perspectives on medicines-traditional medicine-growing needs and potential. No. 2. World Health Organization, Geneva

World Bank (2004) Indigenous knowledge-local pathways to global development. Knowledge and Learning Group, Africa Region, The World Bank, Washington

\section{Submit your manuscript to a SpringerOpen ${ }^{\circ}$ journal and benefit from:}

- Convenient online submission

- Rigorous peer review

- Immediate publication on acceptance

- Open access: articles freely available online

- High visibility within the field

- Retaining the copyright to your article

Submit your next manuscript at $\boldsymbol{\nabla}$ springeropen.com 